\title{
Sejarah Pemikiran Kebangsaan Jakob Oetama Pada Surat Kabar Kompas 1970-2001
}

Annida Allim Nusaibah ${ }^{1 *}$, Abrar $^{2}$, Sri Martini ${ }^{3}$

${ }^{1}$ Universitas Negeri Jakarta; annidalim@gmail.com

${ }^{2}$ Universitas Negeri Jakarta; abrar_unj@yahoo.com

${ }^{3}$ Universitas Negeri Jakarta; srimartini7271@gmail.com

"Korespondensi

Dikirim: 03-06-2021; Diterima: 16-07-2021; Diterbitkan: 19-07-2021

\begin{abstract}
Nationality is needed by every Indonesian as one of the efforts to continue maintaining the unity and integrity of the nation. One of the national press figures who seriously think about the issue of nationality is Jakob Oetama. One of the ways Jakob Oetama channeled national ideology was through the press media named the Kompas. The purpose of this study was to find out how Jakob Oetama ideology about nationality in Kompas newspaper. The period is from 1970 to 2001 . The research method uses historical research methods consisting of four stages; heuristics, verification, interpretation and historiography. The results showed that Jakob Oetama's national ideology in the first Kompas daily newspaper was Bhinneka Tunggal Ika and national ideology, national integration and disintegration, religious issues, knowing the homeland, and the principle of transcendental humanism.
\end{abstract}

Keyword: ideology; Jakob Oetama; nasionality

Abstrak: Pemahaman kebangsaan sangat diperlukan oleh setiap rakyat Indonesia sebagai salah satu upaya untuk terus mempertahankan persatuan dan kesatuan bangsa. Salah satu tokoh pers nasional yang serius memikirkan persoalan tentang kebangsaan adalah Jakob Oetama. Cara Jakob Oetama menyalurkan pemikiran kebangsaan salah satunya yaitu lewat media pers yang diberi nama surat kabar Kompas. Tujuan penelitian ini adalah untuk mengetahui bagaimana pemikiran Jakob Oetama tentang kebangsaan pada surat kabar Kompas periode tahun 1970 sampai dengan tahun 2001. Penelitian ini menggunakan metode penelitian sejarah yang terdiri dari empat tahap yaitu, heuristik, verifikasi, interpretasi dan historiografi. Hasil penelitian menunjukan bahwa pemikiran kebangsaan Jakob Oetama pada surat kabar harian Kompas adalah Bhinneka Tunggal Ika dan ideologi kebangsaan, integrasi dan disintegrasi nasional, persoalan agama, mengenal tanah air, dan prinsip humanisme transendental.

Kata Kunci: Jakob Oetama; kebangsaan; pemikiran

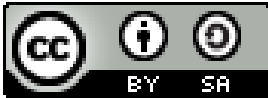

Jurnal Fajar Historia is licensed under a Creative Commons AttributionShareAlike 4.0 International License. 
Annida Allim Nusaibah, Abrar, Sri Martini

Sejarah Pemikiran Kebangsaan Jakob Oetama Pada Surat Kabar Kompas 1970-2001

\section{Pendahuluan}

Negara Kesatuan Republik Indonesia merupakan negara yang majemuk karena keanekaragamannya. Integrasi seolah menjadi masalah sosial yang tidak pernah selesai, bahkan selalu menghadapi kekuatan-kekuatan disintegrasi (Kuntowijoyo, 1999). Konflik yang sering terjadi seperti menjelekkan penganut agama lain, pelanggaran HAM, rasa etnosentrisme, praktik kekerasan dalam kasus tertentu, dan masih banyak lagi merupakan bukti bahwa minimnya kesadaran warga negara Indonesia untuk menjaga persatuan negara dan bangsa.

Minimnya kesadaran warga negara Indonesia untuk terus menjaga rasa persatuan secara tidak langsung terkikis oleh keanekaragaman yang ada. Untuk mencari titik temu di tengah keanekaragaman tersebut dibutuhkan rasa toleransi. Toleransi merupakan suatu sikap atau perilaku manusia yang mengikuti aturan, dimana seseorang dapat menghargai dan menghormati terhadap perilaku orang lain (Bakar, 2015). Toleransi adalah sikap yang paling sederhana, tetapi mempunyai dampak yang positif bagi proses integrasi bangsa pada umumnya dan secara khusus menjaga kerukunan masyarakat dengan sikap toleransi, maka perbedaan yang dapat memicu terjadinya konflik secara tidak langsung bisa diminimalisir. Toleransi tumbuh karena ada rasa kebangsaan yaitu "rasa" dan tumbuh semangat kebangsaan dari senasib dan sepenanggungan, akibat penjajahan dalam sejarah Indonesia.

Konflik-konflik yang terjadi akibat perbedaan yang ada bisa melunturkan rasa kesatuan dan persatuan. Tetapi, hal ini bisa dicegah yaitu dengan cara memahami konsep kebangsaan. Bangsa dalam arti antroplogis adalah perkumpulan suatu masyarakat yang hidup dan masing-masing anggota memiliki rasa satu kesatuan ras, agama, bahasa dan latar belakang kehidupan dimasa lalu. Sedangkan dalam pengertian politik, bangsa adalah suatu political unity merupakan suatu kesatuan dimana masing-masing anggota mungkin saja berbeda kebudayaan, adat istiadat atau kebiasaannya, akan tetapi mereka merasa satu tanggung jawab yang sama untuk mewujudkan negeri yang damai dan sejahtera (Fahrudin, 2020).

Kebangsaan merupakan cara pandang yang mengutamakan persatuan dan kesatuan dalam kehidupan berbangsa, bernegara dan bermasyarakat. Rasa kebangsaan mempunyai sifat yang berarti menyatukan sejumlah masyarakat dalam hal suku, bahasa, budaya, adat istiadat, rasa sepenanggungan dan cita-cita. Pemahaman mengenai kebangsaan sangat diperlukan, khususnya untuk generasi muda yaitu guna meningkatkan rasa nasionalisme dalam diri mereka, sebab sering kali sifat materialistik mengubah idealisme yang merupakan jiwa dari rasa kebangsaan. 
Annida Allim Nusaibah, Abrar, Sri Martini

Sejarah Pemikiran Kebangsaan Jakob Oetama Pada Surat Kabar Kompas 1970-2001

Biografi tokoh pers nasional yang memikirkan persoalan tentang kebangsaan adalah Jakob Oetama. Jakob Oetama lahir pada 27 September 1931 di desa Borobudur, Magelang, Jawa Tengah. Beliau anak dari pasangan R. J Brotosoesiswo dan M.Kartonah (Oetama, 2009). Tahun 1961, beliau memutuskan untuk menjadi seorang wartawan dengan tujuan mendidik masyarakat Indonesia. Menurutnya, wartawan merupakan seorang seniman sekaligus ilmuwan. Pembauran otak dan hati menjadikan wartawan bersikap kritis dan bekerja optimal. Surat kabar dipilih sebab surat kabar merupakan media cetak yang lebih banyak dibaca masyarakat luas dibandingkan majalah dan buku dimana isinya menyangkut berbagai aspek seperti, pemerintahan, politik, ekonomi, kemajuan teknologi, pendidikan, kebudayaan, bencana alam dan berita penting yang perlu diketahui masyarakat. Pada surat kabar Kompas, Jakob Oetama biasa menuliskan pemikirannya lewat tajuk rencana yang ditulisnya dua atau tiga hari sekali selama bertahun-tahun dari awal didirikannya Kompas (Oetama, 2001b). Tajuk rencana adalah rubrik yang membawakan visi atau opini sebuah surat kabar tentang sesuatu atau beberapa hal.

Sebagai contoh tulisan tajuk rencana yang ditulis oleh Jakob Oetama berjudul "Apakah Kita Sepaham, yang Kita Hadapi Adalah Krisis Kebangsaan” edisi 06 Oktober 1998. Jakob Oetama sependapat dengan ungkapan krisis kebangsaan yang dikemukakan oleh Jenderal Wiranto. Jakob Oetama mengungkapkan bahwa telah terjadi kekeliruan interpretasi dan praktek dalam manjalankan falsafah negara yaitu Pancasila dan UUD 1945 (Oetama, 1998). Menurutnya, memang benar bahwa pemerintahan Orde Baru telah mampu meningkatkan pembangunan dalam ruang lingkup perekonomian negara tetapi, disisi lain pemerintah juga mengabaikan pemerataan dan keadilan sosial bagi masyarakat. Selain itu, terjadi juga penyalahgunaan kekuasaan sehingga menyebabkan dapat dengan mudah penguasa menjalankan praktek KKN. Dengan kondisi yang seperti itu menyebakan puncak kekesalan masyarakat yaitu terjadi sebuah gerakan reformasi yang disertai dengan berbagai kritik terhadap pemerintah. Terjadilah kondisi dimana kekerasan lawan kekerasan, saling provokasi dan merasa setiap keputusan yang diambil paling benar. Padahal, seharusnya jika krisis kebangsaan semakin mendalam diibaratkan rumah kita bersama terbakar, maka api kita padamkan bersama, bukan sendiri-sendiri (Oetama, 2001b).

Penelitian sebelumnya mengenai Jakob Oetama pernah dilakukan oleh Dimas Adrian Dewanto (2017) dalam thesisnya yang berjudul "Apresiasi Tokoh Pers Indonesia: Studi Perfomance Research untuk Memperkenalkan Pemikiran Tokoh Jakob Oetama" penelitianya terfokus untuk memperkenalkan sosok Jakob Oetama kepada masyarakat dengan menggunakan metode performance research. Pemikiran Jakob Oetomo juga pernah dilakukan oleh Sularto dalam sebuah buku dengan judul "Syukur Tiada Akhir Jejak Langkah Jakob Oetama”. Buku ini menjelaskan bahwa masa depan bangsa Indonesia adalah manusia 
Annida Allim Nusaibah, Abrar, Sri Martini

Sejarah Pemikiran Kebangsaan Jakob Oetama Pada Surat Kabar Kompas 1970-2001

Pancasila, manusia yang berkeadilan sosial. Keberbedaan kedua tulisan di atas dengan penelitian ini ada pada fokus pemikiran kebangsaan Jakob Oetama yang ditulis pada surat kabar Kompas dalam periode 1970-2001.

Alasan penelitian ini mengangkat pemikiran kebangsaan Jakob Oetama karena belum ada tulisan mengenai pemikiran kebangsaan Jakob Oetama sebagai salah satu tokoh pers nasional, yang mana pemikiran kebangsaan ini merupakan suatu upaya untuk mempertahankan dan menjaga rasa persatuan bangsa Indonesia. Permasalahan mengenai pemahaman kebangsaan bagi rakyat Indonesia merupakan hal yang sangat diperlukan. Persatuan dan kesatuan bangsa Indonesia perlu untuk terus dijaga dengan baik. Tidak ada jaminan bahwa persatuan dan kesatuan bangsa Indonesia tidak pernah ditantang (Suseno, 1995). Adapaun rumusan masalah dalam penelitian ini adalah apa pemikiran kebangsaan Jakob Oetama pada surat kabar Kompas periode tahun 1970-2001. Tujuan penulisan ini adalah untuk mengetahui bagaimana pemikiran Jakob Oetama tentang kebangsaan pada surat kabar Kompas periode tahun 1970-2001.

\section{Metode Penelitian}

Metode penelitian pada dasarnya merupakan cara ilmiah untuk mendapatkan data dengan tujuan dan kegunaan tertentu (Sugiyono, 2017). Metode penelitian pada penelitian ini menggunakan metode penelitian sejarah. Tahap pertama dalam penelitian sejarah adalah heuristik. Heuristik merupakan pemilihan dan pengumpulan sumber-sumber yang berisikan informasi mengenai suatu topik penelitian tertentu. Pada tahap ini penulis mengumpulkan sumber-sumber yang terkait dengan biografi dan pemikiran Jakob Oetama serta sejarah surat kabar kompas. Tahap kedua dari penelitian sejarah ini yaitu verifikasi. Penulis melakukan kritik terhadap sumber yang sudah didapatkan secara ekstern dan intern guna menguji keaslian data-data sejarah yang sudah didapatkan. Tahap ketiga yaitu interpretasi atau penafsiran fakta yang telah diverifikasi. Dari fakta-fakta yang ditemukan maka dilakukan penafsiran fakta sejarah yakni penulis mendeskripsikan pemikiran kebangsaan Jakob Oetama pada Surat Kabar Kompas (1970-2001). Tahap terakhir yaitu historiografi berupa proses

penulisan sejarah. Penulis merumuskan penulisan sejarah yang disusun berdasarkan kronologis peristiwa dengan memperhatikan sebab-akibat pada setiap peristiwa.

\section{Hasil Penelitian}

\section{Bhinneka Tunggal Ika}

Bhinneka Tunggal Ika merupakan semboyan negara Indonesia yang menggambarkan kemajemukan masyarakatnya meliputi ras, agama, suku dan berbagai kelompok lainnya. Sebagaimana telah diatur dalam pasal 36A UUD 1945 yang berbunyi "lambang negara ialah Garuda Pancasila dengan semboyan Bhinneka Tunggal Ika”. Semboyan ini, memiliki makna 
meskipun berbeda-beda tetapi tetap satu. Istilah "Bhinneka Tunggal Ika Tan Hana Dharma Mangurua" diambil dari kitab Sutasoma karya Mpu Tantular yang memiliki arti walaupun agama itu kelihatannya berbeda bentuk serta sifatnya, namun pada hakikatnya satu juga (Al Marsudi, 2016). Penggunaan istilah Bhinneka Tungga Ika pada saat itu menggambarkan toleransi keagamaan penganut agama Hindu dan agama Budha (Pursika, 2009).

Jakob Oetama mengungkapkan dalam sebuah acara seminar tahun 1990, dimana acara seminar saat itu mengangkat tema sebuah paham keberagaman. Jakob Oetama memaparkan bahwa rakyat Indonesia berlatar belakang sebagai bangsa yang majemuk. Tetapi, dari kondisi kemajemukan tersebut telah sama-sama dilalui sebuah pergerakan yang berproses dengan waktu yang cukup panjang hingga akhirnya bisa mencapai kesepakatan bersama untuk menjadi sebuah bangsa yang satu dan berwawasan kebangsaan.

Jakob Oetama juga menuliskan dalam surat kabar harian Kompas, bahwa Konsep Bhinneka Tunggal Ika merupakan bentuk mempertahankan dan menghormati kebhinnekaan keberagaman dan kemajemukan (Oetama, 2000a). Menurutnya, telah terjadi gerakan dimana ada kesepakatan untuk menjadi negara Indonesia yang merdeka dan satu bahasa yaitu bahasa Indonesia. Dari yang banyak menjadi satu, dari daerah-daerah seluas Nusantara menjadi satu negara dan satu pemerintahan (Oetama, 2001a). Ketika banyak pilihan untuk mewujudkan tujuan tiap golongan, tetapi tetap saja pendiri bangsa dan rakyat sama-sama sepakat mendahulukan persatuan negara. Tulisan Jakob Oetama (2000a), "Sirkumtansi sejarah menjadi pendorong ke sana. Ke muara persatuan. Itu aspirasi rakyat banyak yang sedang menjadi satu bangsa. Itu juga merupakan aspirasi para pemimpin pergerakan”.

\section{Ideologi Kebangsaan}

Ideologi berasal dari kata Idea yang berarti gagasan atau sebuah buah pikiran, dan dari kata Logia yang berarti suatu ajaran, sehingga ideologi adalah sebuah ilmu atau ajaran tentang gagasan dan buah pikiran (Al Marsudi, 2016). Pancasila terdiri dari dua kata yaitu Panca yang berarti lima dan Sila yang berarti dasar, sehingga mempunyai makna "Lima Dasar". Istilah "sila " juga merujuk kepada arti sebuah aturan yang mengatur perilaku seseorang atau bangsa (Al Marsudi, 2016). Ideologi Pancasila adalah sebuah ideologi hasil kesepakatan bersama yang dirumuskan oleh para pendiri bangsa guna dijadikan sebagai falsafah bangsa Indonesia..

Tahun 1970, dalam tajuk rencana surat kabar kompas edisi 26 November yang berjudul "Pantjasila Bukan Pemetjahbelah" Jakob Oetama mengutarakan bahwa Ideologi Pancasila bukanlah alat pemecahbelah bangsa tetapi merupakan alat pemersatu, pengayom dan pengharmonis dalam kehidupan bernegara (Oetama, 1970). Argumen ini didasarkan dengan melihat realitas yang terjadi pada masa pemerintahan orde lama dimana menurut Jakob 
Oetama, terjadi kesalahan dalam proses penerapan Pancasila. Pada masa tersebut, diterapkan sistem dialektika dalam kehidupan berpolitik jadi wajar saja jika tidak berhasil. Kegagalan ini disebabkan oleh penerapan politik dialektika yang tidak sejalan dengan asas dan semangat Pancasila sehingga menyebabkan kondisi perpecahbelahan bangsa, kondisi masyarakat yang mudah dipecah belah memudahkan PKI untuk mengambil kesempatan guna menjalankan kepentingannya pada masa itu.

Jakob Oetama menegaskan bahwa bukan Pancasila yang menjadi alat pemecahbelah bangsa Indonesia tetapi, proses penerapan Pancasila menggunakan politik dialektika itulah yang memecahbelah bangsa. Bukan Pancasilanya yang harus dikritisi tetapi caranya yang tidak tepat itu yang akhirnya menjadikan kegagalan dalam menerapkan falsafah bangsa Indonesia. Penggunaan metode dialektika sebaiknya dihindari sebab akan membangkitkan gerakan komnisme bawah tanah. Selain itu, Jakob Oetama juga menyampaikan bahwa politik dialektika tidak mungkin diterapkan pada pemerintahan orde baru sebab, fokus pemerintahan orde baru adalah pembangunan nasional yang mana jika tetap diberlakukan akan merugikan pemerintah itu sendiri. Masyarakat dituntut harus tetap kritis untuk mengahadapi persoalan agar tidak mudah terbawa arus yang bisa dengan mudah memecahbelah persatuan bangsa.

Jakob Oetama juga menyampaikan pemikirannya tahun 1989 dalam sebuah acara Sarasehan perayaan 25 tahun Kompas. Jakob menyatakan bahwa masa depan bangsa Indonesia adalah manusia Pancasila, manusia yang berkeadilan sosial. Pancasila merupakan ideologi terbuka yang akan mampu membina bangsa dan negara untuk tetap peka menghadapi berbagai perubahan mendasar di bagian dalam ataupun luar kehidupan bangsa dan negara Indonesia (Sularto, 2015). Bukan hanya dari masyarakatnya saja tetapi, pemerintah juga harus memiliki sikap keterbukaan, sehingga kehidupan bernegara tidak menjadi totaliterisme.

Pada tahun 1991, Jakob Oetama juga menuliskan dalam tajuk rencana surat kabar harian Kompas yang berjudul "Kita Senantiasa Harus Hadirkan Ideologi Kita dalam Masyarakat" yang terbit pada Selasa, 27 Agustus (Oetama, 1991). Pada tulisannya dalam tajuk, Jakob Oetama menuliskan bahwa ideologi Pancasila adalah ideologi yang terbuka sebab, terbuka dengan berbagai macam aspirasi dari masyarakat, pembaharuan dari perkembangan zaman serta akan terus manjadi rujukan untuk menjawab segala hal dalam tantangan pembaharuan perubahan zaman. Jakob Oetama juga menegaskan bahwa Ideologi Pancasila jangan sampai hilang dari kehidupan masyarakat Indonesia. Keruntuhan ideologi Komunisme dan partai komunis di Eropa Timur bisa dijadikan pembelajaran bagi bangsa Indonesia bahwa ideologi bisa runtuh dalam kehidupan bernegara.

Pada tahun 1995, saat peringatan kemerdekaan bangsa Indonesia yang ke-50 tahun. Jakob Oetama mengatakan dalam pidatonya bahwa ideologi Pancasila merupakan kerangka 
Annida Allim Nusaibah, Abrar, Sri Martini

Sejarah Pemikiran Kebangsaan Jakob Oetama Pada Surat Kabar Kompas 1970-2001

referensi dalam persoalan paham kebangsaan. Menurutnya, bangsa Indonesia membangun secara sengaja paham kebangsaan tersebut dari kemajemukan seluruh masyarakat Indonesia. Ideologi Pancasila yang terbuka diharapkan dapat menjadi rujukan kebersamaan dan keberagaman masyarakat Indonesia dalam kehidupan bernegara dengan lansadan warisan peristiwa sejarah yang sudah dialami dan menjadi kesepakatan para pendiri bangsa Indonesia.

Dalam pidato peringatan hari kemerdekaan ke-50 bangsa Indonesia itu, Jakob Oetama juga megegaskan kembali serta mengajak seluruh masyarakat Indonesia untuk tetap berpegang teguh kepada ideologi Pancasila dan menjadikan Pancasila sebagai landasan untuk sama-sama meningkatkan rasa kebersamaan dalam persatuan dan kesatuan. Ideologi Pancasila harus selalu menjadi titik temu atas semua persoalan bangsa. Selain itu, Jakob Oetama juga mengingatkan bahwa setiap masyarakat Indonesia harus sadar jika negara Indonesia berdiri atas kemajemukan masyarakatnya maka, paham kebangsaan harus selalu didahulukan supaya tidak mudah terjadi konflik antar kelompok agama, daerah dan etnis. Bila paham kebangsaan selalu dijaga maka, akan tercipta kehidupan yang aman bagi seluruh masyarakat Indonesia. Bahasan mengenai kebangsaan dan persatuan harus selalu dihidupakn, disadari dan dikembangkan seiring dengan perubahan dan kondisi zaman (Oetama, 2001a).

\section{Integrasi dan Disintegrasi Nasional}

Integrasi nasional adalah sebuah upaya untuk mempersatukan segala perbedaan yang ada pada suatu negara, sehingga tercipta kehidupan yang harmonis secara nasional. Pada tahun 1990, Jakob Oetama menuliskan tentang persoalan integrasi nasional. Dalam tulisannya Jakob Oetama memberikan contoh peristiwa yang terjadi di negara lain yaitu Lebanon. Lebanon adalah negara bermasyarakat majemuk yang sebelumnya hidup dalam kerukunan tetapi terjadi perang saudara yang berlangsung dari tahun 1975 hingga tahun 1990. Peritiwa yang terjadi di Lebanan dicontohkan oleh Jakob Oetama dengan tujuan supaya masyarakat Indonesia bisa lebih mudah memahami arti dan peranan dari integrasi nasional. Karena apa yang terjadi di Lebanon bukan tidak mungkin akan bisa terjadi di Indonesia sebab Indonesia juga memiliki masyarakat yang majemuk.

Untuk menjelaskan mengenai persoalan intergrasi nasional Jakob Oetama menggunakan istilah nation and character building. Nation and character building adalah upaya untuk memperbaiki dan membentuk karakter masyarakat Indonesia dalam kehidupan bernegara, sehingga sesuai dengan falsafah Pancasila dan berwawasan kebangsaan. Jakob Oetama mengungkapkan bahwa Indonesia yang masih berumur muda sebagai suatu bangsa tidak boleh mengabaikan proses integrasi nasional. Usaha nation and character building harus tetap on going effort, upaya dan karya yang tak kenal berhenti (Oetama, 2001a). 
Annida Allim Nusaibah, Abrar, Sri Martini

Sejarah Pemikiran Kebangsaan Jakob Oetama Pada Surat Kabar Kompas 1970-2001

Salah satu cara untuk berproses pada integrasi nasional adalah dengan melakukan pembangunan nasional. Sebab pembangunan merupakan sebuah perubahan yang dilakukan dengan sengaja dan terstruktur. Jika ada sebuah pembangunan berarti segala sesuatu yang terlibat di dalamnya sudah menjadi suatu hal yang direncanakan dengan pernuh pertimbangan dengan tujuan mencapai hasil yang maksimal. Pentingnya perencanaan dalam proses suatu pembangunan yang dilakukan secara nasional adalah supaya tidak terjadi halhal yang bisa melemahkan karakter masyarakat. Sebab, telah banyak kita saksikan dan rasakan akibat dari sebuah pembangunan yang tidak direncanakan dengan baik, dampaknya juga berpengaruh pada nation dan character building. "Dalam prosesnya, akibat-akibat itu mengendorkan tali-tali simpul kemantapan integrasi nasional, ikut mengganggu keseimbangan yang semula dirasakan ada dalam kelompok-kelompok masyarakat" (Oetama, 2001a).

Selain integrasi nasional, Jakob Oetama juga mengemukakan pemikirannya mengenai disintegrasi nasional. Disintegrasi nasional adalah pemisahan atau perpecahan kesatuan (Dewi, 2016). Pada masa lampau para pendiri bangsa dan seluruh rakyat sepakat memilih bahwa kesatuan adalah bentuk negara Indonesia dan republik adalah bentuk pemerintahannya sehingga menjadi Negara Kesatuan Republik Indonesia (NKRI) yang kemudian menjadi wadah untuk menampung aspirasi seluruh rakyat Indonesia. Implikasi dari penentuan NKRI ini, membuat tatanan pemerintahan menjadi terpusat. Akibat pemusatan yang terjadi berkembanglah sentralisasi yang berlebihan. Sentralisasi yang berlebihan akhirnya membuat aspirasi dari daerah-daerah kurang diperhatikan. Kurangnya pemenuhan aspirasi dari rakyat yang ada di daerah-daerah menimbulkan ketidakpuasan atas sikap pemerintah pusat. Karena dirasa pemerintah pusat tidak bisa mewadahi semua aspirasi rakyat, maka timbul sebuah gerakan yang oleh Jakob Oetama disebut sebagai gerakan arus balik sejarah. Dimana menurut Jakob Oetama gerakan ini terjadi akibat dari kekecewaan sebagian masyarakat yang terlalu lama diperlakukan tidak adil oleh pemerintah.

Gerakan arus balik sejarah ini merupakan sebuah gerakan disintegrasi nasional karena rakyat berusaha mencari kembali wadah yang bisa mewujudkan aspirasi kerakyatan dan membangun kembali sebuah rumah yang disebut sebagai bangsa dan negara. Gerakan arus balik sejarah adalah sebuah respons dari rakyat atas rasa kecewa yang dirasakannya dan menganggap pemerintah pusat tidak bisa mewujudkan aspirasinya. "Terlalu lama rakyat dan daerah ditekan, terlalu lama rakyat dan daerah diperlalukan tidak adil, terlalu lama terjadi pemusatan kekuasaan, sentralisasi dan daerah diperlakukan tidak adil secara politik, ekonomi dan sosial budaya" (Oetama, 2000b).

Contoh gerakan arus balik sejarah terjadi pada 21 Mei 1998, yaitu peristiwa mundurnya Soeharto sebagai Presiden Republik Indonesia. Sebelum peristiwa mundurnya Soeharto telah 
terjadi beberapa demontrasi yang dilakukan oleh mahasiswa dan rakyat dari berbagai golongan. Demontrasi yang terjadi pada 12 Mei 1998 menuntut reformasi tersebut berakhir rusuh hingga 15 Mei 1998. Menurut pemberitaan dari surat kabar harian Kompas edisi 14 Mei (1998) dalam kerusuhan massa juga terdapat aksi perusakan dan pembakaran terhadap bangunan dan kendaraan bermotor khususnya di Jakarta. "Kerusuhan bermula dari kawasan di sekitaran kampus Trisakti yaitu Jalan Daan Mogot, jalan Kyai Tapa, Jalan S Parman hingga menjelang sore hari aksi perusakan dan pembakaran meluas ke kawasan Bendungan Hilir, Kedoya, Jembatan Besi, Bandengan Selatan, Tubagus Angke, Semanan, Kosambi” (Kompas, 1998)

Jakob Oetama juga menyampaikan pendapatnya pada peringatan hari Sumpah Pemuda yang ke-72 tahun tepatnya pada Sabtu, 10 Oktober tahun 2000 dalam tajuk rencana surat kabar harian Kompas yaitu menuliskan bahwa keadaan bangsa Indonesia sedang terjadi gerakan arus balik sejarah yang akhirnya membawa keadaan bangsa Indonesia berada dalam bayangan ancaman disintegrasi nasional. Jakob Oetama menjadikan momentum hari peringatan Sumpah Pemuda menjadi hari pengingatan kembali atas apa yang sudah bangsa Indonesia khususnya kaum pemuda sepakati di masa lampau. "Dari kemajemukan yang oleh sistem kolonialisme dijadikan landasan devide et impera, pecah belah dan dikuasai, diubah menjadi satu bangsa, satu tanah air, satu bahasa. Indonesia!" (Oetama, 2000b). Keadaan yang terjadi sudah tidak seperti apa yang disepakati oleh para pendiri bangsa. Menurut Jakob Oetama, hanya tinggal kesepakatan bahasanya saja yang masih digunakan oleh masyarakat Indonesia yaitu penggunaan bahasa Indonesia.

\section{Agama}

Jakob Oetama mengutarakan bahwa ada hubungan antara agama dengan paham kebangsaan. Menurut Jakob (2001a) "organisasi kemasyarakatan yang terkuat dan paling nyata kehadirannya di Indonesia adalah dari kalangan agama-agama", maka dari itu jelas bahwa faktor agama memiliki peranan untuk menyatukan bangsa. Contoh peristiwa sejarah yang memperlihatkan peranan organisasi keagamaan yaitu seperti yang terjadi di kota Surabaya pada 22 Oktober 1945, adanya sebuah seruan dari organisasi Islam "Nahdlatul Ulama" kepada seluruh umat muslim untuk mempertahankan kemerdekaan Indonesia dari penjajahan. Seruan tersebut dikenal dengan sebutan resolusi jihad.

Pada pertengahan tahun 1970'an Jakob Oetama melihat telah terjadi pola masyarakat yang mulai mengesampingkan nilai agama atau yang Jakob Oetama sebut sebagai "timbul kekosongan rohani”. Masyarakat mulai mengesampingkan nilai keagamaan karena disebabkan oleh maraknya konsumerisme dan materialisme yang lambat laun mempengaruhi pola kehidupan masyarakat. Orientasi masyarakat hanya bertuju pada materi. Jakob Oetama 
Annida Allim Nusaibah, Abrar, Sri Martini

Sejarah Pemikiran Kebangsaan Jakob Oetama Pada Surat Kabar Kompas 1970-2001

sangat menyayangkan fenomena tersebut, sebab menurutnya agama adalah sumber kebajikan serta keteguhan dalam berkarakter sekalipun dalam bidang politik.

Perubahan pola masyarakat dalam mengamalkan nilai-nilai agama menjadikan masyarakat rawan melakukan kesalahan dalam mengartikan nilai-nilai keagamaan. Hal ini menjadikan pemahaman agama dalam kehidupan masyarakat berkembang keluar bebas sesuai interpretasi masyarakat. Sehingga mengakibatkan aliran agama berkembang keluar dari idealnya suatu nilai agama. Jakob Oetama menyampaikan kecemasannya bahwa jika pengamalan agama yang tidak sesuai dengan hakekatnya akan menyebabkan agama mudah jatuh ke dalam interpretasi dan rekayasa yang tidak sesuai dengan nilai sesungguhnya. Karena interpretasi yang tidak sesuai dengan nilai sesungguhnya, maka juga akan menyebabkan pengamalan yang tidak sesuai.

Ketidaksesuaian ini dikhwatirkan akan membuat agama menjadi pembatas dalam kehidupan bermasyarakat bukan menjadi rahmat bagi seluruh umat. Menurut Jakob Oetama, terjadi penghayatan agama secara primodial. Sikap primodialisme ini jika dibiarkan berkembang dalam kehidupan akan membawa konflik dalam masyarakat yang berujung pada hilangan rasa kebangsaan dalam kehidupan. Sebab, sudah tidak ada lagi rasa saling menjaga dan pemahaman mengenai satu kesatuan dalam kehidupan yang diakibatkan karena konflik yang terjadi.

\section{Mengenal Tanah Air}

Ungkapan mengenal tanah air merupakan gagasan Jakob Oetama yang digunakannya untuk terus menjaga rasa persatuan bangsa Indonesia. Menurut Jakob Oetama, bangsa Indonesia memiliki kekayaan alam yang sangat berlimpah. Tetapi, kita sebagai rakyat bangsa Indonesia tidak mengenal secara rinci apa saja potensi yang dimiliki oleh bangsa Indonesia. Gerakan mengenal tanah air, bisa menumbuhkan rasa kepedulian antar rakyat Indonesia sebab dengan mempelajari apa saja yang ada dalam bangsa Indonesia kita belajar untuk mengetahui kelebihan dan kekurangan tiap wilayah. "Cinta tanah air diekspresikan dan diamalkan secara lebih mencakup wajah dan panorama alam, kemudahan dan kekhasannya, sumber kekayaannya serta tantangan dan persoalan ekologinya (Sularto, 2015)".

Pasca tahun 1990-an gerakan mengenal tanah air ini dipraktikkan dengan lebih intensif, Jakob Oetama aplikasikan pada surat kabar harian Kompas dengan membuat sebuah program yaitu diadakannya ekspedisi-ekspedisi Nusantara dengan melakukan berbagai liputan mendalam seperti ekspedisi Tanah Papua, ekspedisi Flores dan Nusa Tenggara Timur, ekspedisi Bengawan Solo, ekspedisi Mamberamo, ekspedisi Anjer-Panarukan, ekspedisi Ciliwung, ekspedisi Sungai Musi, ekspedisi Cincin Api dan ekspedisi kuliner. Ada juga program jelajah sepeda di berbagai daerah yang bernama "Jelajah Sepeda Sabang- 
Annida Allim Nusaibah, Abrar, Sri Martini

Sejarah Pemikiran Kebangsaan Jakob Oetama Pada Surat Kabar Kompas 1970-2001

Merauke”. Selain itu, juga terdapat program pengenalan mengenai kekayaan alam Indonesia, budaya dan kesenian daerah.

Jakob Oetama berpendapat bahwa sangat diperlukan untuk mengangkat dan mengumumkan melalui berbagai media khususnya media cetak mengenai kelebihan dan kekurangan secara mendalam apa yang dimiliki oleh bangsa Indonesia. Dengan diangkatnya pemberitaan mengenai tanah air, maka akan membuat masyarakat dan pemerintah semakin memahami kelebihan dan kekurangan yang ada. Sehingga, bisa dijadikan acuan untuk terus mengembangkan diri dan sebagai pijakan untuk membuat kebijakan yang sesuai dengan permasalahan yang sedang dihadapi. Kebijakan yang dibuat bisa menyelesaikan segala persoalan dengan cara yang tepat. Selain itu, dengan mengenal tanah air merupakan salah satu cara yang efektif untuk terus menumbuhkan rasa kebangsaan. Karena dengan mengenal tanah air menandakan masyarakat juga turut serta menjaga warisan sejarah, seni budaya, adat istiadat dan kekayaan alam yang ada di Indonesia.

\section{Prinsip Humanisme Transendental}

Humanisme transendental adalah sebuah prinsip yang digagas oleh Jakob Oetama yang digunakan untuk menjalankan surat kabar harian Kompas. Menurut Jakob Oetama, humanisme transendental ini adalah sebuah bentuk pengamalan dari ideologi Pancasila. Dalam gagasannya ini, Jakob Oetama mengemukakan bahwa manusia bukanlah objek tetapi sebagai subjek, sedangkan media massa yaitu pers digunakan sebagai wadah untuk menampung suaranya (Hendarto, 2020).

Istilah humanisme transendental pertama kali muncul dalam sebuah wawancara dengan Jakob Oetama sebagai narasumber dan Kees de Jong sebagai pewawancara pada tahun 1990. Dalam wawancara tersebut didapat sebuah kesimpulan bahwa Jakob Oetama mendapatkan gagasan humanisme transendental dari ideologi Pancasila. Kata humanisme didapat dari ideologi Pancasila yang selalu dijadikan sebagai landasan dan usaha manusia untuk mengatasi segala kekurangan dalam kehidupan. Sedangkan, transendental adalah sebuah pengharapan kepada Tuhan Yang Maha Esa atas segala perbuatan yang dilakukan sebagai usaha manusia ini hanyalah semata-mata ditujukan untuk mendapat rahmat-Nya.

Humanisme adalah sebuah paham yang menaruh keyakinan pada martabat manusia. Memposisikan manusia sebagai subjek yang mempunyai hak asasi manusia (Hendarto, 2020). Konsep ini diwujudkan Jakob Oetama saat memimpin surat kabar harian Kompas yaitu dengan memanusiakan manusia dengan tidak menjadikan karyawan sebagai tenaga pemenuhan bisnis semata tetapi tetap memberikan dan menghargai setiap hak-haknya sebagai manusia. Sedangkan, konsep transendental diwujudkan sebagai etika dalam penerbitan berita pada surat kabar harian Kompas. Menurut Jakob Oetama, dalam melakukan 
Annida Allim Nusaibah, Abrar, Sri Martini

Sejarah Pemikiran Kebangsaan Jakob Oetama Pada Surat Kabar Kompas 1970-2001

pemberitaan, sebuah pers tidak boleh berlandaskan atas dasar rasa suka/tidak suka atau menggunakan pers sebagai media kepentingan pribadi. Tetapi harus dikejakan secara serius, jujur, benar dan profesional.

Humanisme transendental merupakan hubungan yang vertikal karena berhubungan langsung dengan Tuhan Yang Maha Esa dan juga hubungan yang horizontal karena terdapat hubungan dengan sesama individu, masyarakat, bangsa dan negara. Gagasan humanisme transendental dianggap sebagai kultur dari sistem masyarakat pancasila. Menurut Jakob Oetama masyarakat pancasila adalah membangun masyarakat yang memegang tinggi nilai religiusitasnya, tanpa harus menjadi negara agama. Sebab, bangsa Indonesia tidak mungkin menjadi negara agama karena persatuan bangsa di dirikan atas dasar keberagaman termasuk dalam bidang agama. Gagasan humanisme transendental merupakan sebuah cara untuk mewujudkan Pancasila dalam masyarakat Indonesia. Sebuah ideologi yang bukan sekedar dihafal tetapi juga diamalkan dalam kehidupan sehari-hari.

\section{Simpulan}

Kebangsaan merupakan cara pandang yang mengutamakan persatuan dan kesatuan dalam kehidupan berbangsa, bernegara dan bermasyarakat. Rasa kebangsaan mempunyai sifat yang berarti menyatukan sejumlah masyarakat dalam hal suku, bahasa, budaya, adat istiadat, rasa sepenanggungan dan cita-cita. Pemahaman mengenai kebangsaan sangat diperlukan, guna meningkatkan rasa nasionalisme dalam setiap jiwa rakyat Indonesia. Jakob Oetama merupakan salah satu tokoh nasional yang berperan penting dalam perkembangan pers di Indonesia. Jakob Oetama sebagai salah satu tokoh pers nasional Indonesia senantiasa mengajak rakyat Indonesia untuk terus mempertahankan serta meningkatkan rasa persatuan dan kesatuan. Hal ini terlihat melalui pelbagai tulisannya di dalam surat kabar harian Kompas. Adapun pemikiran kebangsaan yang dituliskan Jakob Oetama pada surat kabar Kompas periode 1970-2001 meliputi, Bhinneka Tunggal Ika, ideologi Pancasila, integrasi nasional dan disintegrasi nasional, persoalan agama, dan mengenal tanah air serta prinsip humanisme transendental.

\section{Ucapan Terimakasih}

Puji syukur peneliti panjatkan kepada Allah SWT yang telah memberikan rahmat, karunia dan pertolongan-Nya, sehingga peneliti bisa menyelesaikan penelitian ini. Ucapan terimakasih peneliti utarakan kepada semua pihak yang telah mendukung dan membantu peneliti selama melakukan penelitian. Kepada para dosen pembimbing, peneliti ucapkan terimakasih atas kesabaran dan arahannya kepada penulis selama membimbing peneliti melakukan penelitian. Kepada kedua orangtua peneliti ucapkan terimakasih atas doa, semangat dan pelbagai bantuan yang diberikan kepada peneliti selama melakukan penelitian. Serta tidak lupa ucapan terimakasih kepada seluruh teman-teman peneliti atas bantuan yang diberikan kepada penulis selama melakukan penelitian. 
Annida Allim Nusaibah, Abrar, Sri Martini

Sejarah Pemikiran Kebangsaan Jakob Oetama Pada Surat Kabar Kompas 1970-2001

\section{Daftar Rujukan}

Al Marsudi, S. (2016). Pancasila dan UUD’45 dalam Paradigma Reformasi. Jakarta: Rajawali Pers.

Bakar, A. (2015). Konsep Toleransi Ddn Kebebasan Beragama. Toleransi, 7(2), 123-131. https://doi.org/10.24014/trs.v7i2.1426.

Dewanto, D. A. (2017). Adrian Apresiasi Tokoh Pers Indonesia (Studi Perfomance Research untuk Memperkenalkan Pemikiran Tokoh Jakob Oetama). Tesis. Malang: Universitas Brawijaya.

Dewi, I. M. (2016). Konflik dan Disintegrasi di Indonesia. Jurnal Ilmu Sosial dan Humaniora, 6(1), 91-102. https://doi.org/10.21831/moz.v6i1.4400.

Fahrudin, A. (2020). Nasionalisme Soekarno Dan Konsep Kebangsaan Mufassir Jawa. Jakarta: Litbangdiklat Press.

Hendarto, Y. M. (2020). Humanisme Transendental: Warisan Pemikiran Jakob Oetama. Bapak Jakob Oetama Kisah Kecil Bermakna Besar. Jakarta: PT. Kompas Media Nusantara.

Kuntowijoyo. (1999). Budaya dan Masyarakat.Yogyakarta: Tiara Wacana.

Kompas. (1998). Jakarta Dilanda Kerusuhan Massa. 14 Mei. Halaman 1. Jakarta.

Oetama, J. (1970). Pantjasila Bukan Pemetjahbelah. Harian Kompas. 26 November. Halaman 2. Jakarta.

Oetama, J. (1991). Kita Senantiasa Harus Hadirkan Ideologi Kita dalam Masyarakat. Harian Kompas, Halaman 4. Jakarta.

Oetama, J. (1998). Apakah Kita Sepaham, yang Kita Hadapi Adalah Krisis Kebangsaan. Harian Kompas. 6 Oktober. Jakarta.

Oetama, J. (2000a). Merangsang Pemikiran Ulang Keindonesiaan. Harian Kompas Kompas. 28 Oktober. Halaman 25. Jakarta.

Oetama, J. (2000). Terhadap Sumpah Pemuda, Apakah Sedang Terjadi Arus Balik Sejarah? Harian Kompas. 28 Oktober. Halaman 4. Jakarta.

Oetama, J. (2001a). Berpikir Ulang Tentang Keindonesian. Jakarta: PT. Kompas Media Nusantara.

Oetama, J. (2001b). "Suara Nurani" Tajuk Rencana Pilihan 1991-2001. Jakarta: PT. Kompas Media Nusantara.

Oetama, J. (2009). Bersyukur dan Menggugat Diri. Jakarta, PT. Kompas Media Nusantara.

Pursika, I. N. (2009). Kajian Analitik Terhadap Semboyan "Bhinneka Tunggal Ika”. Jurnal Pendidikan dan Pengajaran, 42(1), 15-20. http://dx.doi.org/10.23887/jppundiksha.v42i1\%20Apr.1726. 
Annida Allim Nusaibah, Abrar, Sri Martini

Sejarah Pemikiran Kebangsaan Jakob Oetama Pada Surat Kabar Kompas 1970-2001

Sugiyono. (2017). Metode Penelitian Kuantitatif, Kualitatif, dan R\&D. Bandung, Alfabeta.

Sularto, S. (2015). Syukur Tiada Akhir Jejak Langkah Jakob Oetama. Jakarta, PT. Kompas Media Nusantara.

Suseno, F. M. (1995). Persatuan Indonesia: Pancasila Paham Kebangsaan dan Integrasi Nasional. Pancasila Sebagai Ideologi Terbuka Problema dan Tantangan. Jakarta: Kanisius. 